\title{
URGENCY COGNITIVE-BEHAVIORAL COUNSELING BASED ON LOCAL WISDOM FOR JUNIOR HIGH SCHOOL COUNSELOR IN EAST JAVA
}

\author{
Nur Hidayah ${ }^{1}$, M. Ramli², Husni Hanafi ${ }^{3}$ \\ ${ }^{1}$ Department of Guidance and Counseling, Faculty of Education, State University of Malang, Indonesia \\ ${ }^{2}$ Department of Guidance and Counseling, Faculty of Education, State University of Malang, Indonesia \\ ${ }^{3}$ Postgradute program, State University of Malang
}

Corresponding e-mail: nur.hidayah.fip@um.ac.id

\begin{abstract}
The cultural encounters of counselors-counselees have great influence to the success of counseling services. Counseling services in Indonesia still use western theory, have not considered the value of eastern culture. One of the study of Indonesian culture, especially East Java contains uniqueness in presenting the process of counseling aid. East Java has seven ethnics namely Osing, Tengger, Madura, Java, Samin, Materaman, and Bawean. The study of the seven East Java ethnics will give birth to a new paradigm of eastern cultural counseling-local wisdom. The positive impact of counseling services cultural-based has strategic value: building internal and external counseling service imaging, facilitating counselors while serving counselees with culture diversity with appropriate change techniques, and Cognitive-Behavioral Counseling based on local wisdom becomes new counseling paradigms in Indonesia especially in East Java. CognitiveBehavioral Counseling framework is a form of counseling that incorporates the principles and procedures of Cognitive counseling and Behavioral counseling in an effort to help the counselee in achieving expected behavioral changes.
\end{abstract}

Keywords: $\quad$ urgency, Cognitive-Behavioral Counseling, local wisdom

\section{INTRODUCTION}

The counseling paradigm of local wisdombased is important because the counseling paradigm is a framework for service delivery. The findings of previous studies in the counseling process rarely consider of local cultural values-rather than local wisdom-based counseling. A gap is observed that Madura ethnic counselors in providing assistance to ethnic Madura counselee purely use the paradigm of counseling from Anglo sexion, for example America. It also happens to ethnic Javanese counselors, Tengger, Osing, Samin, Materaman, and Bawean. Less complete problem solving in counseling, because of less attention to the values of local wisdom. Similarly, counseling relation situations often occur-counselor and counselees encounters with different cultures have not been a concern at the time of transactions in counseling. A surprising phenomenon in East Java that a counselee slapped a counselor during the counseling process.

Counseling as an assistance service that establishes counselees is built on the altruist motives of counselors by promoting the welfare and happiness of the counselee. Provision of optimal counseling services, required for counselors to pay attention to the factors that affect the effectiveness of counseling. One of the factor that influence the continuity of counseling is cultural values.

One of counseling model to help students ethnic-based is Cognitive-Behavioral Counseling based on local wisdom. Counseling model based local wisdom in Indonesia are still rare. Some research results test the effectiveness of CognitiveBehavioral Counseling still purely use the paradigm Cognitive-Behavioral Counseling initiated by [1], [2]. The research findings of Cognitive-Behavioral Counseling is effective to improve the self-regulated learning of Junior High School students in Malang Raya [1], [4], [5] Thus Cognitive-Behavioral Counseling is effective to improve self-esteem of high school students [6] and Cognitive-Behavioral Counseling effectively tested to improve the academic self-efficacy of junior high school students in Malang [7]. The findings of the study have not yet considered local cultural values.

Testing of Cognitive-Behavioral Counseling model as the previous research findings, 
its implementation take a direct [1], [2]. Characteristics of Cognitive-Behavioral Counseling based on local wisdom needs to develop the model and its paradigmatic uniqueness, thus giving birth to framework Cognitive-Behavioral Counseling based on local wisdom of East Java. Development of the new Cognitive-Behavioral Counseling framework ranging from human views, counseling characteristics, conditions and change mechanisms include counseling techniques. New framework of Cognitive-Behavioral Counseling based on local wisdom can be used by counselor East Java. Cognitive-Behavioral Counseling model based on local wisdom can help counselor professional growth. In turn, it encourages counselor feel happy and confident in providing counseling services and reduce the confusion of counselor's praxis when applying the chosen counseling model.

Based on some of these studies, then the matters related to how are the local cultural values of East Java, especially Madura, Tengger, and Samin ethnics are internalized in the model of CognitiveBehavioral Counseling? Conceptually, the internalization of Madura, Tengger, and Samin cultures requires deeper elaboration.

\section{STUDY OF EAST JAVA SOCIETY CULTURE}

East Java society consists of seven ethnics, namely: Osing, Tengger, Madura, Java, Bawean, Samin, and Materaman.

\subsection{Madura Ethnic Society}

Madura is one of the ethnic from Madura island in East Java which has a considerable population in Indonesia. Nature that tends to rocky and barren rocks make most residents of Madura migrate to other areas to earn income by working or trading. The Madura are very strong with culture values and philosophy of life that is used as a guide in living everyday life. The philosophical values of the Madura, namely (1) hard work attitude, (2) selfawareness, (3) attitudes of service, (4) brave attitude, (5) attitude away from corruption and usury, (6) attitude of evading lousy thing , (7) caution on harassment, and (8) attitude of helping others.

[8] describes the characteristics of the Madura in terms of psychological well-being, it has six aspects, namely (1) the ability of a person to evaluate himself as a positive person, (2) personal growth, (3) positive relations with others, (4) autonomy, (5) the ability to manage life and nature of the environment effectively (environmental mastery), and (6) the belief that one's life leads to a purpose and meaningful life.

\subsection{Samin Ethnic Society}

Samin society is a society that has a unique identity and adhere to the teachings of Saminism. This Samin teaching contains three laws governing the behavior of the Samin community, namely: (1) angger-angger pengucap (speech law); (2) anggerangger pertikel (laws of conduct); and (3) anggerangger lakunana (implementation law).

Angger-angger pengucap are the law of speech or speech with others. Samin society should talk that does not hurt other people, they should think carefully before talking. Becoming a Samin society do not speak easily and they have to speak true thing. This explains that the speech or speech of the word for the Samin community is really important and needs to be considered.

Angger-angger pertikel are a law of conduct based on: honesty, patience, harmony, mutual respect, and benefit for others. The Samin community needs to avoid behaviors such as srei, dengki, dahwen, nyolong, petil, apus meaning jealousy, envy, confessing something that is not hers, and stealing items that are not hers, stingy, and prudent. These angger-angger are made by parents in educating their children by emphasizing good deeds to others and stay away from actions that harm themselves and others.

Angger-angger lakunana, is the third law about the actions that should be done by the Samin community after understanding the two previous laws namely Angger-angger pengucap and Anggerangger pertikel. This third law reads "lakonan sabar trokal, sabare dieling-eling and trokale dilakoni. This shows that under any circumstances the Samin community is required to keep trying and to do as much as possible with a sense of patience in achieving the desired goal. The purpose of life in the world is happy, kind, harmonious, fresh, and healthy. All these things are the impact of a companion to someone who managed in finding the meaning of his life. Thus Angger-angger lakunana is interpreted as a manifestation of Angger-angger pengucap and Angger-angger pertikel.

\subsection{Tengger Ethnic Society}

The people of Tengger are people who live on the slopes of Tengger and Semeru mountains ". [9] explains that: 
"Tengger's meaning can also be analyzed from the Tengger people's myth of husband and wife (Rara Anteng and Jaka Seger) who first inhabited the area, where the two couples had 25 children, one of them (Raden Kusuma) sacrificed as a victim by throwing him out of the Crater of Mount Bromo for the sake of the safety of his brothers, then the name of Tengger is an abbreviation of the word "Teng" from Anteng and "Ger" from Seger which means the nature is not much whim and not easily disturbed, which is reflected in the people of Tengger until now.

[9] added that the character of Tengger society is that the people are obedient to the leader (sabda pandhita ratu), obedient to carry out the tradition, such as the celebration of the big day and traditional ceremonies. Many customary activities are conducted by Tengger community, because they have great respect and glorify their ancestors. In addition to respect his ancestors, traditional ceremonies are also used by the community to strengthen relationships among the people. That way the community always remain harmonious and always connected well.

According to [10], " Tengger people believe in spirits of the dead and the spirits of the dead are believed to be alive and are personified as the village attendant and who are respected and given the offerings in order not to be angry. Tengger people always perform special rituals as a form of homage to their ancestors in certain months, such as Kasada and Karo ceremonies ". Both ceremonies are the greatest ceremonies and the ceremonies are important for Tengger people.

[10], states that " Tengger people believe in the law of karma". It makes them always do good things and always try to keep harmony between citizens. Tengger people also always use the way deliberation to consensus in solving problems. This is similar to the expression [9] who said that:

"In solving every problem, Tengger people prioritize discussion based on the welas asih pepitu (seven compassionate) consists of welas asih marang Bapa Kuasa (God), welas asih marang ibu pertiwi (land), welas asih marang bapa-biyung (parents), welas asih marang rasa jiwa (soul), welas asih marang sepadhane urip (people), welas asih marang sato kewan (aimal), welas asih marang tandur tetuwuh (plants)".
[9] and [14] argued that the teachings of panca sroda include not to harm or kill animals, except for sacrificial animals or for consumption, not misbehave, not stealing, not lying, not drinking alcohol. Tengger people believe that if they do abstinence (panca sroda), then the result is much bigger and heavier than the crime that has been done.

The twenty wills of ancestors are a guideline used by society to act in everyday life. [9] states:

"The doctrine of the 20 testaments used as a basis by the Tengger society, that the living person should have good manners, prevent the fancy food, make it simple, prevent sleepiness so that sleep does not need to exaggerate, can control himself, everyone is obliged carrying out the teachings of God, everyone should be grateful to the Great Hyang, help each other especially to those who are affected by misfortune or distress, like feeding the starving people, giving an umbrella to those who are in the rain, giving hoods to those who are hot, giving drinks to those who are thirsty, give the staff to those who slip, point the way to the lost, remind each other when there are those who are neglected (forgot themselves), can tolerate the actions of the guilty person until the person in turn will regain consciousness of his sin and his guilt everyone is friendly to the guests, each person forgive each other, should people do not pretentious, should people not feel the greatest and most intelligent, people should not feel themselves the most wealthy because all of it is really merely God, Sang Hyang Agung.

The three ethnic studies inherent in the East Java society have illustrated the creative peculiarities in working, appreciating the meaning of truth, virtue, and religious beliefs, and acting on the philosophy of each ethnic group. Cultural values that are believed by East Java people become the foundation to develop a counseling model based on local wisdom. The Cognitive-Behavioral Counseling framework was developed based on the ethnic distinctives of Madura, Tengger, and Samin Java, resulting in human nature, the nature of counseling, conditions and counseling mechanisms, and counseling techniques. 


\section{COGNITIVE-BEHAVIORAL COUNSELING BASED ON LOCAL WISDOM}

The Cognitive-Behavioral Counseling model is an integrative counseling model between cognitive counseling orientation and behavioral counseling developed by [2]. As rational emotive counseling views cognition consists of an irrational belief system. Cognitive therapy views cognition consist of irrational thoughts. Rational emotive counseling philosophy and Cognitive therapy underlies the development of Cognitive-Behavioral Counseling [1], [12].

Cognitive-Behavioral Counseling framework is a form of counseling that incorporates principles and procedures of cognitive counseling and behavioral counseling in an effort to help the counselee achieve expected behavioral changes ([11]; [12]; [13]). The purpose of CognitiveBehavioral Counseling is to help the counselee identify and alter specific cognitive processes related to his affective and behavioral problems. More specifically, the purpose of Cognitive-Behavioral Counseling is to assist the counselee (1) managing awareness of the patterns of cognition-behavioraffection relationships experienced by counselee. The counselor asks counselees to monitor their thoughts, feelings, and behaviors that occur before, during, and after a particular problem situation; (2) managing a new set of cognitions that can be used and influencing counselees to change by compiling behavioral cognition alternatives new affective that can replace cognition, behavior and misfortune; (3) managing the competencies needed to overcome the weaknesses of the counselee by encouraging counselees to practice new cognitive patterns in life both in the form of closed and open behavior; And (4) improving the effectiveness of counselee competence in developing new cognitions, behaviors, affections as defined.

The stages of Cognitive-Behavioral Counseling are: Initial Phase (First) .The first stage of Cognitive-Behavioral Counseling is data collection. This stage aims to help the counselee to determine the problems encountered and formulate the goals of counseling. Therefore counselors train counselees become good observers of their own behavior. At this stage, the counselee makes the diary to monitor the behavioral objectives that will be changed, answer the questionnaire, take the test, and so on. At this stage it is expected that (1) the counselee realizes that the data relating to the problem he/she has experienced has never been considered even being ignored, and (2) counselee's self exploration affect the process of reconceptualization of the problems encountered, so that can be resolved effectively.

Middle Stage (Second). The second stage of Cognitive-Behavioral Counseling is a stage of improvement of cognitive, emotional, and behavioral changes. This stage aims to help counselees manage their adaptive thoughts and behaviors. Once the counselee begins to redefine the problem, the counselee learns to implementation complex new behavior or produce behavior that fits the new situation. In this second phase the counselee is expected to achieve change in three domains, namely (1) change of open behavior, (2) self regulated activity, in this case counselor cooperate with counselee to help change self statement, self image and feeling that interferes adaptive function, and (3) changes in the cognitive structure of the counselee.

Final Stage (Third). The third stage is the stage of consolidation, generalization, behavior maintenance, and avoidance of recurrence. This stage involves the cognition and role of the counselee about change. During this final phase the counselor and counselee consolidate the changes achieved, improve the generalization and maintenance of counseling influence and reduce the possibility of counselee to relapse again. At this stage the counselor is expected to help the counselee (1) be able to link the changes that have been achieved with his repertoire, and (2) increase the sustainability of the benefits of counseling experienced with the anticipation of recurrence at any time.

The Cognitive-Behavioral Counseling model has been developed through research. The author's first work in 2007 was the guidance on the use of collaborative counseling ICT-Based, in 2010 developing the REBT counseling guide, in 2013 developing the online counseling guide, and the author's last work in 2015 was Cognitive-Behavioral Cybercounseling through Skype or Bistri. For 10 years applying counseling learning research and technology informatics based in Guidance and Counseling Department and was disseminated through community service activity in the form of online counseling training to counselor in Malang Raya.

Related to ethnic-based counseling model has strategic value to (1) build internal counseling service imaging by the counselor profession and BK profession external- psychologist, psychotherapist, is a professional service based on local wisdom; (2) 
facilitate counselor while serving culture diverse counselee using appropriate conversion techniques in accordance with cultural values of the counselee. In addition counselor are expected to actually grow problem solving appropriately. In turn, counselor are happy when providing counseling services; (3) Cognitive-Behavioral Counseling based on local wisdom becomes a new counseling paradigm in Indonesia especially in East Java; and (4) disseminating the importance of CognitiveBehavioral Counseling service based on local wisdom for students, so that the preparation of the future human resources of our nation increase its quality.

Furthermore, developing the model of Cognitive-Behavioral Counseling based on local wisdom is developed by integrating values of culture/ethnic in East Java-Tengger, Madura, and Samin ethnic. By developing the paradigm of counseling based on local wisdom, the counselor's competence is grown in order to consciously take care of local culture. With the hope of counseling this local wisdom can provide counselors aware of the importance of caring counselee-counselor culture, thus giving birth to a literate character generation.

\section{CONCLUSION}

The Cognitive-Behavioral Counseling model is one of the counseling models originally developed by Aron [1] to assist traumatized counselees. As its development is implemented by [2] to assist negative-minded counselees, it affects negative affections and behaviors as well. Many research studies prove that Cognitive-Behavioral Counseling is efficacious to help improving selfregulated learning of low counselees. Similarly, another study examined the self-esteem level of the counselee is increased with Cognitive-Behavioral Therapy (CBT) intervention.

In this study the authors consider it urgent that CBT is developed based on the local wisdom of East Java, especially the Madura, Tengger, and Samin Java, resulting in human nature, the nature of counseling, conditions and mechanisms change in counseling, and counseling techniques. Thus, CBT used by counselors really have value added that is based on local culture of East Java. In turn, the counselor becomes aware of caring for the local culture.

\section{REFERENCES}

[1] Beck, A.T. 1976.Cognitive Therapy and the Emotional Disorders. New York: A Meridian Book.

[2] Beck, J.S. 2011. Cognitive-Behavior Therapy Basic and Beyond. 2 ${ }^{\text {nd }}$. New York: The Guildford Press Spring Street.

[3] Hidayah, N, dkk. 2007. "Pengembangan Model Konseling Kolaboratif Berbasis ICT". Laporan Penelitian. Tidak dipublikasikan. Malang: Lemlit Universitas Negeri Malang.

[4] Hidayah, N, dkk. 2013. Pengembangan Model Konseling Online Untuk Mengembangkan SRL Siswa SMP se-Malang Raya. Laporan Penelitian. Tidak dipublikasikan. Malang: LP2M Universitas Negeri Malang.

[5] Hidayah, N, 2015. Cognitive-Behavioral Cybercounseling To Improve Junior High School Student's Self Regulated Learning. International Journal Academic Research. ESSN 2075-7107. 7 (4), $241 \square 243$.

[6] Muawanah, E. 2014. Keefektifan Cognitive Restructuring Untuk Meningkatkan SelfEsteem Siswa SMA. Disertasi. Tidak dipublikasikan. Malang: PPs Universitas Negeri Malang.

[7] Wicaksono, L. 2015. Keefektifan Konseling Modifikasi Kognitif Perilaku Untuk Meningkatkan Efikasi Diri Akademik Siswa SMP. Disertasi. Tidak dipublikasikan. Malang: PPs Universitas Negeri Malang.

[8] Muslihati. 2014. Nilai-nilai Psychological wellbeing dalam Budaya Madura dan Kontribusinya pada Pengembangan Kesiapan Karir Remaja Menghadapi Bonus Demografi. Jurnal Studi Sosial. 6 (2), $120 \square 125$.

[9] Adrianto, A, dkk. 2013. Kearifan Lokal. Yogyakarta: Balai Pelestarian Nilai

[10] Waluyo, H. 1997. Sistem Pemerintahan Tradisional di Tengger Jawa Timur. Jakarta: CV. Putra Sejati Raya.

[11] Corey, Gerald. 2009. Theory and Practice for Counseling and Psychotherapy. $8^{\text {th }}$. ed. California: Brooks/Cole.

[12] Corey, Gerald. 2013. Theory and Practice for Counseling and Psychotherapy. $9^{\text {th }}$. ed. Belmont: Brooks/Cole.

[13] Ramli, M. 2005. "Terapi Perilaku Kognitif". Artikel. Dalam Mamat Supriatna (2005). Pendidikan dan Konseling di Era Global. Bandung: BK UPI. 
[14] Trianto \& Tutik, T. W. 2008. Perkawinan Adat Wologoro Suku Tengger. Surabaya: Prestasi Pustaka.

[15] Hidayah, N, dkk. 2010. Pengembangan Model Konseling REB untuk Mengelola SRL Konseli.

Laporan Penelitian. Tidak dipublikasikan. PHKI Program Studi BK FIP UM. Malang: Universitas Negeri Malang

[16] Budaya (BPNB) Daerah Istimewa Yogyakarta. 